\title{
Physiological Potential of Seeds of Perennial Soybean cv. Comum Coated with Different Materials
}

\author{
Priscilla Brites Xavier, Henrique Duarte Vieira \\ Department of Technology and Seed Production, State University of North Fluminense Darcy Ribeiro, Campos dos Goytacazes, \\ Brazil \\ Email:pri_brites@yahoo.com.br
}

How to cite this paper: Xavier, P.B. and Vieira, H.D. (2018) Physiological Potential of Seeds of Perennial Soybean cv. Comum Coated with Different Materials. American Journal of Plant Sciences, 9, 1-12. https://doi.org/10.4236/ajps.2018.91001

Received: September 29, 2017

Accepted: January 7, 2018

Published: January 10, 2018

Copyright (c) 2018 by authors and Scientific Research Publishing Inc. This work is licensed under the Creative Commons Attribution International License (CC BY 4.0).

http://creativecommons.org/licenses/by/4.0/

\section{(c) () Open Access}

\begin{abstract}
The aim of this study was to evaluate the effect of different seed coatings on the physiological potential of perennial soybean $\mathrm{cv}$. Comum. The following treatments were tested: control (no coating); limestone + polyvinyl acetate (PVA); limestone + sand + PVA; limestone + charcoal + PVA; calcium silicate + PVA; calcium silicate + sand + PVA; and calcium silicate + charcoal + PVA. Seeds were evaluated for water content (WC), maximum diameter (MAD), minimum diameter (MID), 1000-seed weight (TSW), germination test, germination speed index (GSI), average germination time (AGT), emergence, emergence speed index (ESI), average emergence time (AET), shoot length (SL), root length (RL), dry and fresh matter of shoots (SDM and SFM), and dry and fresh matter of root (RDM and RFM). Coatings influenced GSI, AGT, emergence, and ESI, but germination was unaffected. The use of silicate with or without charcoal led to the same AET as that observed in the uncoated seeds. Coatings did not affect SFM, SDM, or RFM. Coating with limestone + sand + PVA or limestone + charcoal + PVA led to increases in SL, SFM, SDM, RFM, and RDM.
\end{abstract}

\section{Keywords}

Fabaceae, Coating Pan, Germination, Emergence, Vigor

\section{Introduction}

In Brazil, the livestock activity in all regions of the country is founded upon the use of grasslands, mainly native pastures, which is an important feed source for herds. However, cultivated pastures have occupied an ever-increasing space in the Brazilian scenario [1]. The perennial soybean (Neonotonia wightii) adapts 
well to climatic variations and presents good regrowth and closure capacity of the pasture area, in addition, produce hay with high nutritional value and protein concentration. These characteristics make it one of the most used forage legumes in Brazilian pastures [2].

Besides that, the reduced size of its seeds and its nutrient requirements render the perennial soybean a promising species for the seed-coating technique, since this method enables the incorporation of nutrients, growth regulators, and agrochemicals, in addition to facilitating the distribution of seeds both manually or mechanically, as it provides them with a rounder shape and a larger size [3].

According to [4], seed filler materials must have round, uniform granules sized between 0.1 and $0.2 \mathrm{~mm}$; not be hygroscopic, hydrophilic, corrosive, or toxic; not possess surface tension; be sterile; not be a medium for reproduction of microorganisms; be insoluble in water or weak acids; have a density of approximately 1; and be easily found in the market at a cost compatible with the benefit they provide to the seeds. Commonly employed fillers are both soluble and insoluble in water, e.g. vermiculite, sand, dolomitic limestone, kaolin, activated charcoal, microcellulose, cornmeal, wheat bran, cassava starch, corn starch, celite, and diatomaceous earth [3] [5] [6] [7] [8].

Likewise, the cementing or adhesive material must meet some criteria to be used in the process, such as having affinity with the other ingredients; being readily soluble in water; acting at low concentrations; becoming dry and not sticky when dehydrated; forming a low-viscosity solution when rehydrated; and not being hygroscopic, corrosive, or toxic [3]. These materials are usually organic polymers, starches, natural resins, sugars, animal-derived glues, and vegetable mucilages, which can be dispersed in water for the production of a sprayable fluid [9].

However, materials used in the coating process may influence the rates of water absorption and gas exchange between the seed and the external medium, directly affecting germination [10]. The objective of this study was thus to evaluate the effect of different coating materials on the physiological potential of seeds of perennial soybean cv. Comum.

\section{Materials and Methods}

For the experiment, commercial seeds of perennial soybean cv. Comum (Neonotonia wightii) were previously scarified manually between two sheets of 36-grit sandpaper.

Dolomitic limestone (DL; $0.25 \mathrm{~mm}$ ), calcium silicate (CS), sand (S; $0.25 \mathrm{~mm}$ ), and activated charcoal (AC) were used as fillers. As cementing material, we used a polyvinyl acetate glue (PVA) (Cascorez Extra, Cascola ${ }^{\circ}$ ) diluted in water previously heated to $70^{\circ} \mathrm{C}$ at the $1: 1$ ratio (v/v) [7].

The following seed-coating treatments were tested: control (no coating); DL + PVA; DL + S + PVA; DL + AC + PVA $; \mathrm{CS}+\mathrm{PVA} ; \mathrm{CS}+\mathrm{S}+\mathrm{PVA}$; and CS + AC + PVA. 
The following filler-to-seed ratios were employed according to [11]: limestone$3: 1(\mathrm{w} / \mathrm{w})$, calcium silicate-3:1 $(\mathrm{w} / \mathrm{w})$, sand-1:1 $(\mathrm{w} / \mathrm{w})$, and activated charcoal $-0.08: 1(\mathrm{w} / \mathrm{w})$. The amounts of limestone, calcium silicate, and sand were divided into 12.5 -g portions, whereas the charcoal was divided into 2-g portions so that the filler could be applied in layers.

We used a bench-top coating pan (Newpack N10) equipped with a stainless steel tank, nozzle for the application of cementing material activated by compressed air at a pressure of 4 bar, hot-air blower, and timer to regulate the duration of the spray and the dryer. The machine was regulated to operate at a rotation speed of $90 \mathrm{rpm}$, spraying duration of $1 \mathrm{~s}$, blower temperature of $40^{\circ} \mathrm{C}$, and blowing time of $1 \mathrm{~min}$. The seed-coating procedure (per layer) was performed following the methodology of [11].

After their reception, seeds were evaluated for their physical and physiological characteristics in laboratory and greenhouse. In the laboratory, the following physical characteristics were determined: water content (WC), maximum seed diameter (MAD), minimum seed diameter (MID), and 1000-seed weight (TSW). The following physiological characteristics were evaluated using the germination test in paper: first germination count (FGC), germination speed index (GSI), and average germination time (AGT). In a greenhouse, the following physiological characteristics were evaluated by the emergence test: emergence speed index (ESI), average emergence time (AET), shoot length (SL), root length (RL), shoot fresh and dry matter (SFM and SDM), and root fresh and dry matter (RFM and $\mathrm{RDM})$. The procedures adopted for the aforementioned assessments are described below:

Water content (WC)-determined in two replicates by the oven method at $105^{\circ} \mathrm{C} \pm 3^{\circ} \mathrm{C}$ for $24 \mathrm{~h} \mathrm{[12]}$, with results expressed in percentage values (wet basis).

Maximum diameter (MAD) and minimum diameter (MID) - determined using four replicates with 50 seeds for each coating treatment, which were analyzed by the GroundEye image analysis system to determine the largest and smallest diameters, respectively.

1000 -seed weight (TSW)-determined from eight replicates of 100 seeds per treatment [12].

Germination test-conducted according to the Rules for Seed Analyses [12], with four replicates of 50 seeds for each treatment. Seeds were sown in a germination box containing two sheets of germination paper moistened with deionized water at a volume of 2.5 times the paper weight and kept for 10 days in a B.O.D. chamber at an alternating temperature of $20^{\circ} \mathrm{C} / 35^{\circ} \mathrm{C}$. Evaluations were carried out four and 10 days after the start of the test (first-count [FCG] and final [G] germination, respectively), by counting the number of normal seedlings, abnormal seedlings (AS), and hard seedlings (HS), according to the criteria established by [12]. Throughout the test, daily counts were performed to determine, at the end, the average germination time (AGT), according to [13]. The 
germination speed index (GSI) was determined, using the Equation (1) proposed by [14]:

$$
G S I=G 1 / N 1+G 2 / N 2+\cdots+G n / N n
$$

where $G S I=$ germination speed index; $G 1, G 2, \cdots G n=$ number os seeds germinated in the first, second to last count; $N 1, N 2, \cdots N n=$ number of days from sowing to first, second to last count.

Emergence test-in a greenhouse, the seeds were sown in plastic trays with capacity for $2.2 \mathrm{~L}$ of substrate, containing a mixture of sand and soil (2:1) (v/v). The greenhouse was covered with shading screen $35 \%$ shade (Sombrite) and clear plastic $150 \mu \mathrm{m}$ thick. On the sides, it was covered only with the same Sombrite ${ }^{\circledR}$. The number of emerged seedlings was counted daily, for 30 days. At the end, we determined the percentage of emergence, the emergence speed index (ESI) [14], and the average emergence time (AET) [13]. At the end of the 30 days, plants were carefully removed from the trays and their roots were properly washed to measure the length of shoots (SL) and root (RL). Subsequently, shoots and root were weighed to determine the fresh matter of shoots (SFM) and root (RFM). Next, they were placed in paper bags and dried in a forced-air oven at $65^{\circ} \mathrm{C}$ for $72 \mathrm{~h}$ to determine the shoot dry matter (SDM) and root dry matter (RDM).

The laboratory experiments were analyzed as a completely randomized design for the following variables: WC, MAD, MID, G, AS, HS, FCG, GSI, and AGT. For the variables emergence, ESI, AET, SL, RL, SFM, SDM, RFM, and RDM, a randomized-blocks design was adopted. To determine TSW, a descriptive analysis of the data was performed. Data pertaining to WC, first-count germination, and GSI were converted to $1 / \mathrm{x} \arcsin (\mathrm{x} / 100)^{1 / 2}$ and $\sqrt{\mathrm{x}}$, respectively, to follow normal distribution.

Data were subsequently subjected to analysis of variance and means were compared by the Duncan test at the $5 \%$ probability level, using the ASSSISTAT 1.6 beta software [15].

\section{Results and Discussion}

According to the descriptive analysis of 1000-seed weight (TSW) (Table 1), the proposed coating materials led 1.2 to 1.9 higher increases in the coated seeds as compared with control treatment. This increase in TSW as a function of the filler material was also observed in coated seeds of sorghum, super sweet corn, pearl millet, Stylosanthes, and perennial soybean [7] [11] [16] [17] [18].

The coating composed of limestone + sand + PVA provided the highest TSW $(10.68 \mathrm{~g})$, followed by the treatment with dolomitic limestone + activated charcoal + PVA ( $8.89 \mathrm{~g})$. The use of calcium silicate led to increases of up to $58 \%$ in TSW, whereas the use of limestone provided a $94 \%$ increase in TWS (Table 1).

[7] also found great increases in the TSW of coated seeds of super sweet corn as a function of the addition of urea and limestone to the filler. The authors observed increases of $100 \%$ to $150 \%$, respectively, in TSW, when these materials 
Table 1. Thousand seed weight (TSW), Maximum diameter (MAD), Minimum diameter (MID), Water content (WC), First germination count (FGC), Germination speed index (GSI), Average germination time (AGT), Germination (G), Abnormal seedlings (AS) and Hard seedlings (HS) of soybean cv. Comum seeds coating with the following treatments: Control - no coating; DL + PVA - dolomitic limestone + PVA; DL + S + PVA - dolomitic limestone + sand + PVA; DL + AC + PVA - dolomitic limestone + activated charcoal + PVA; CS + PVA - calcium silicate + PVA; CS + S + PVA - calcium silicate + sand + PVA; CS + AC + PVA - calcium silicate + activated charcoal + PVA.

\begin{tabular}{ccccccccccc}
\hline Treatment & $\begin{array}{c}\text { TSW } \\
(\mathbf{g})\end{array}$ & $\begin{array}{c}\text { MAD } \\
(\mathrm{mm})\end{array}$ & $\begin{array}{c}\text { MID } \\
(\mathrm{mm})\end{array}$ & $\begin{array}{c}\text { WC } \\
(\%)\end{array}$ & $\begin{array}{c}\text { FGC } \\
(\%)\end{array}$ & GSI & $\begin{array}{c}\text { AGT } \\
(\text { days })\end{array}$ & G (\%) AS (\%)HS (\%) \\
\hline Control & 5.50 & $2.60 \mathrm{c}$ & $1.77 \mathrm{~d}$ & $10.0 \mathrm{a}$ & $35 \mathrm{a}$ & $8.83 \mathrm{a}$ & $4.25 \mathrm{a}$ & $55 \mathrm{a}$ & $13 \mathrm{a}$ & $10 \mathrm{c}$ \\
$\mathrm{DL}+$ PVA & 8.45 & $2.82 \mathrm{~b}$ & $2.19 \mathrm{~b}$ & $6.5 \mathrm{~d}$ & $6 \mathrm{bc}$ & $5.25 \mathrm{c}$ & $5.68 \mathrm{~cd}$ & $48 \mathrm{a}$ & $7 \mathrm{a}$ & $7 \mathrm{c}$ \\
$\mathrm{DL}+\mathrm{S}+$ PVA & 10.68 & $2.87 \mathrm{a}$ & $2.30 \mathrm{a}$ & $5.7 \mathrm{f}$ & $4 \mathrm{c}$ & $4.92 \mathrm{c}$ & $6.58 \mathrm{~d}$ & $49 \mathrm{a}$ & $10 \mathrm{a}$ & $13 \mathrm{bc}$ \\
$\mathrm{DL}+\mathrm{AC}+$ PVA & 8.89 & $2.81 \mathrm{~b}$ & $2.20 \mathrm{~b}$ & $6.4 \mathrm{~d}$ & $4 \mathrm{c}$ & $5.37 \mathrm{bc}$ & $6.36 \mathrm{~d}$ & $53 \mathrm{a}$ & $10 \mathrm{a}$ & $9 \mathrm{c}$ \\
$\mathrm{CS}+$ PVA & 6.75 & $2.81 \mathrm{~b}$ & $2.09 \mathrm{c}$ & $7.5 \mathrm{~b}$ & $9 \mathrm{bc}$ & $6.28 \mathrm{bc}$ & $5.30 \mathrm{bc}$ & $50 \mathrm{a}$ & $11 \mathrm{a}$ & $9 \mathrm{c}$ \\
$\mathrm{CS}+\mathrm{S}+$ PVA & 8.73 & $2.86 \mathrm{a}$ & $2.28 \mathrm{a}$ & $6.1 \mathrm{e}$ & $4 \mathrm{c}$ & $5.07 \mathrm{c}$ & $6.07 \mathrm{~cd}$ & $47 \mathrm{a}$ & $10 \mathrm{a}$ & $19 \mathrm{a}$ \\
$\mathrm{CS}+\mathrm{AC}+$ PVA & 7.23 & $2.83 \mathrm{ab}$ & $2.10 \mathrm{c}$ & $7.1 \mathrm{c}$ & $17 \mathrm{~b}$ & $6.84 \mathrm{~b}$ & $5.08 \mathrm{ab}$ & $54 \mathrm{a}$ & $9 \mathrm{a}$ & $18 \mathrm{ab}$ \\
Mean & - & 2.80 & 2.13 & 7.04 & 11.3 & 6.08 & 5.62 & 50.9 & 10 & 12.1 \\
CV (\%) & - & 0.87 & 1.12 & 1.17 & 42.59 & 8.10 & 10.27 & 16.56 & 36.22 & 31.88
\end{tabular}

$\mathrm{CV}=$ coefficient of variation. PVA = polyvinyl acetate glue. Averages followed by same letter in the column do not differ from each other by the Duncan test, at $5 \%$ probability.

were added. Likewise, [19] observed increases of up to $100 \%$ in the TSW of Persea indica as they increased the doses of NPK fertilizer added to the filler with sand and limestone. According to [11], the texture of limestone and sand favor the formation of a structure with more granules around the seed, which consequently increases its mass. As a result, the combination of these materials promoted the highest TSW values.

Fillers including sand (DL + S + PVA and CS + S + PVA) provided the highest values for MAD and MID; however, the treatment containing $\mathrm{CS}+\mathrm{AC}+$ PVA did not differ from those for MAD. For these variables, the particle size of the sand likely contributed to the formation of thicker layers, which resulted in an increased diameter of the seeds.

The increase in diameter and TSW constitutes an advantage obtained from the coating technique, since it facilitates sowing, be it mechanical or manual [3] [20].

All coated seeds showed lower water contents (WC) as compared with the uncoated seeds (Table 1). This is a result of the almost complete degradation of the filler material during drying that occurs in the formation of the layers. However, among the evaluated treatments, those including sand in their composition $(\mathrm{DL}+\mathrm{S}+\mathrm{PVA}$ and CS $+\mathrm{S}+\mathrm{PVA})$ stood out for resulting in the lowest WC, which was probably a consequence of the low water-retaining ability of sand during the drying process.

Lower WC values in coated seeds were also detected by [11] [21] [22]. [21] 
stated that the water present in the coating is lost faster than that found in the seed itself; for this reason, coated seeds usually have lower WC values than uncoated seeds.

[23] and [24], on the other hand, obtained conflicting results for this variable in the coating of carrot and soybean seeds, respectively. Coated carrot seeds had a WC of $24.1 \%$, whereas control treatment had a WC of $7.8 \%$, which led to a $16.3 \%$ increase in this variable. In the case of coated soybean seeds, this increase was lower $(0.9 \%)$, but still none of the coating treatments promoted WC values below that shown by control. This was certainly a result of the lack of drying after the coat was applied and/or use of a high volume of adhesive material.

These results indicate that the method used in the drying of the pellets after coating was not effective, thus requiring a new drying session, as was reported by [23] for carrot seeds. Therefore, this drying step is a noteworthy factor, especially if seeds are stored for a later rather than immediate use.

It should be stressed that the results obtained in this study for the WC variable indicate that the methodology adopting the Newpack coating pan was efficient in coating the seeds, since the materials did not retain moisture originating from the application of the cementing solution, and that the temperature of $40^{\circ} \mathrm{C}$ was sufficient to dry them. The use of the temperature of $40^{\circ} \mathrm{C}$ was also efficient in drying coated seeds of Stylosanthes, perennial soybean, and Persea indica [11] [18] [19], which reinforces the effectiveness of this seed-coating method.

None of the coating treatments was superior to control in the first germination count (FGC) (Table 1). Over the course of the test, we observed that the coatings influenced the water-imbibing speed of the seeds, which lengthened the first phase of the three-phase water absorption pattern, consequently slowing the germination process. Similar results were found in lettuce seeds coated using the INCOTEC technology [25].

Results obtained for FGC reflected in the germination speed index (GSI) and average germination time (AGT), for which the seeds showed the same response (Table 1). Several authors reported a delay in the germination of coated seeds [5] [6] [7] [21] [26]. This delay is due to the material employed in the coating process, which forms a physical barrier that should be overcome by the seed. However, some materials facilitate the gas and water diffusion between the seed and the external medium [3].

The CS + AC + PVA coating led to similar a AGT to that shown by the uncoated seeds (Table 1), which may be related to the peculiar characteristics of these two materials (CS and AC). During the test, calcium silicate would dissolve more easily when in contact with water. The activated charcoal was obtained from the pyrolysis (chemical decomposition brought about by heat) of plant-derived carbonated materials, followed by chemical activation, and, lastly, the formation of an adsorbent material with high porosity [27]. The characteristics of these two materials combined may have favored radicle protrusion, since the barrier generated by them did not constitute a great impediment to germination. These characteristics of calcium silicate and activated charcoal were also 
emphasized by [11] in the coating of seeds of Stylosanthes, in which the addition of one of these materials or the combination of both promoted similar AGT values to those obtained with control treatment.

Just as some materials can facilitate the exchange of gases and water between the seed and the external medium, others can hinder this diffusion, as was observed in the treatments containing limestone and/or sand (DL + PVA; DL + S + PVA; DL + AC + PVA; and CS + S + PVA) (Table 1). As mentioned previously, limestone and sand lead to the formation of thicker coating layers. According to [28], these characteristics of limestone may form a seal on the coat against gas exchanges, as observed by [26] in coated tomato seeds.

The main problem caused by coating is related to delays in seed germination and plant emergence [5]. However, the delay observed in the germination of the seeds (low GSI and high AGT) as a function of coating did not compromise the final germination rates (Table 1), indicating that, irrespective of coating, the seedlings were able to make up for this time. Similar results were found in seeds of lettuce coated with different proportions of bentonite and PVA [5] and seeds of Stylosanthes coated with the same materials tested here [11]. Overall, after overcoming the barrier provided by coating, the seedlings had their growth speed equaled that of seedlings from uncoated seeds, ultimately generating uniform plants [10].

As shown in Table 1, for abnormal seedlings (AS), although the barrier generated by coating can hinder gas exchanges and water absorption, the percentage of such plants decreased in a non-significant manner, likely as a consequence of the slower water absorption, causing less damage to the membranes during imbibing.

Results for the percentage of hard seeds (HS) revealed an effect of coating (Table 1). [11] asserted that these findings may be related to flaws during the mechanical scarification of the seeds with the sandpaper. However, it is possible that the crevices generated by mechanical scarification were filled by the cementing material applied during the coating process, reestablishing part of the hardness of the teguments of the perennial-soybean seeds.

Overall, the coated seeds had lower values for ESI and higher AET (Table 2). However, the seeds coated with CS + PVA and CS + AC + PVA showed values similar to those obtained with control treatment for AET. These results confirm the visual observation that silicon-containing coatings dissolve more easily than limestone coatings when in contact in water, whereas the characteristic porosity of charcoal showed to exert a positive effect on AET, unlike the limestone and the sand.

[26] also observed delayed emergence of tomato seedlings as a function of coating with limestone. However, this negative effect of limestone was not observed for sorghum seeds [16]. This lower permeability attributed to limestone may be a result of its particle size, which contributed to the formation of more-resistant pellets, consequently leading to the formation of a more-resistant 
Table 2. Emergence (E), emergence speed index (ESI), average emergence time (AET), shoot length (SL), root length (RL), shoot fresh matter (SFM), shoot dry matter (SDM), root fresh matter (RFM) and root dry matter (RDM) of soybean cv. Comum plants from seeds coated with the followings treatments: Control - no coating; DL + PVA - dolomitic limestone + PVA; DL + S + PVA - dolomitic limestone + sand + PVA; DL + AC + PVA dolomitic limestone + activated charcoal + PVA; CS + PVA - calcium silicate + PVA; $\mathrm{CS}+\mathrm{S}+\mathrm{PVA}$ - calcium silicate + sand + PVA; CS + AC + PVA - calcium silicate + activated charcoal + PVA.

\begin{tabular}{cccccccccc}
\hline Treatment & E (\%) & ESI & $\begin{array}{c}\text { AET } \\
(\text { days })\end{array}$ & $\begin{array}{c}\text { SL } \\
(\mathrm{cm})\end{array}$ & $\begin{array}{c}\text { RL } \\
(\mathrm{cm})\end{array}$ & $\begin{array}{c}\text { SFM } \\
(\mathrm{mg} / \mathrm{pl})\end{array}$ & $\begin{array}{c}\text { SDM } \\
(\mathrm{mg} / \mathrm{pl})\end{array}$ & $\begin{array}{c}\text { RFM } \\
(\mathrm{mg} / \mathrm{pl})\end{array}$ & $\begin{array}{c}\text { RDM } \\
(\mathrm{mg} / \mathrm{pl})\end{array}$ \\
\hline Control & $55 \mathrm{a}$ & $5.35 \mathrm{a}$ & $5.76 \mathrm{a}$ & $1.13 \mathrm{ab}$ & $6.44 \mathrm{ab}$ & $53.76 \mathrm{a}$ & $9.67 \mathrm{a}$ & $35.94 \mathrm{a}$ & $5.82 \mathrm{ab}$ \\
DL + PVA & $43 \mathrm{~b}$ & $3.38 \mathrm{bc}$ & $7.00 \mathrm{bc}$ & $0.86 \mathrm{~b}$ & $4.97 \mathrm{~b}$ & $45.79 \mathrm{a}$ & $7.15 \mathrm{a}$ & $29.46 \mathrm{a}$ & $4.71 \mathrm{~b}$ \\
DL + S + PVA & $47 \mathrm{~b}$ & $3.35 \mathrm{bc}$ & $7.83 \mathrm{c}$ & $1.10 \mathrm{ab}$ & $6.68 \mathrm{ab}$ & $74.45 \mathrm{a}$ & $12.97 \mathrm{a}$ & $43.54 \mathrm{a}$ & $10.11 \mathrm{a}$ \\
DL + AC + PVA & $42 \mathrm{~b}$ & $3.11 \mathrm{c}$ & $7.69 \mathrm{bc}$ & $1.39 \mathrm{a}$ & $7.43 \mathrm{ab}$ & $75.56 \mathrm{a}$ & $13.80 \mathrm{a}$ & $45.78 \mathrm{a}$ & $8.20 \mathrm{ab}$ \\
CS + PVA & $46 \mathrm{~b}$ & $3.91 \mathrm{~b}$ & $6.47 \mathrm{ab}$ & $1.16 \mathrm{ab}$ & $7.60 \mathrm{a}$ & $62.82 \mathrm{a}$ & $10.55 \mathrm{a}$ & $44.87 \mathrm{a}$ & $7.00 \mathrm{ab}$ \\
CS + S + PVA & $46 \mathrm{~b}$ & $3.50 \mathrm{bc}$ & $7.64 \mathrm{bc}$ & $1.03 \mathrm{ab}$ & $7.34 \mathrm{ab}$ & $60.81 \mathrm{a}$ & $10.88 \mathrm{a}$ & $33.58 \mathrm{a}$ & $5.85 \mathrm{ab}$ \\
$\mathrm{CS}+$ AC + PVA & $44 \mathrm{~b}$ & $3.94 \mathrm{~b}$ & $6.34 \mathrm{a}$ & $1.11 \mathrm{ab}$ & $7.39 \mathrm{ab}$ & $62.75 \mathrm{a}$ & $10.01 \mathrm{a}$ & $37.82 \mathrm{a}$ & $6.37 \mathrm{ab}$ \\
Mean & 45.93 & 3.79 & 6.96 & 1.11 & 6.84 & 62.28 & 10.72 & 38.71 & 6.87 \\
CV (\%) & 10.29 & 11.92 & 11.16 & 20.19 & 22.45 & 34.48 & 39.30 & 38.90 & 41.94 \\
\hline
\end{tabular}

$\mathrm{CV}=$ coefficient of variation. PVA = polyvinyl acetate glue. Averages followed by same letter in the column do not differ from each other by the Duncan test, at $5 \%$ probability.

barrier against imbibing and germination. According to [28], the use of limestone in the coating of lettuce seeds provided pellets with greater resistance, while addition of urea to coating caused the pellets to have intermediate resistance. The use of aluminum silicate in the coating of barley seeds did not promote differences in the speed of emergence of the seedlings as compared with uncoated seeds [29], corroborating the present findings for AET.

Based on the results obtained by those authors, it can be inferred that the use of calcium silicate and charcoal in the current study lead to the formation of pellets with lower resistance as compared with those formed by limestone and/or sand; thus, the barrier created by these minerals was also less resistant to root protrusion, contributing to the results found for AET.

Unlike the results for percentage of final germination, in the germination chamber tests, the percentage of emergence of plants originating from coated seeds did not equal that of the SNR at the end of the test (Table 2). In this case, all coating treatments showed to be inferior to control.

Some authors also reported a negative effect of coating on seedling emergence, especially in the case of limestone coatings [10] [26] [30]. [7] observed reductions in the emergence of plants of super sweet corn with filler materials such as sand, charcoal, kaolin (hydrated aluminum silicates), vermiculite, wheat bran, and limestone, and some of these materials were also used in the present experiment. 
Although the coating treatments promoted a reduction in emergence, the final quality of the plants was not affected in the same intensity. Overall, the treatments did not compromise the length of shoots (SL) or root (RL), for which the coatings led to similar results to those obtained for control treatments, although DL + PVA provided the lowest values for these two variables (Table 2).

The lower values observed with the DL + PVA treatment are likely related to the delayed emergence of plants from seeds coated with that material. Results obtained with the coating of soybean seeds with limestone, aluminum silicate, or the combination of both corroborate this hypothesis, since the coatings made with these materials lead to higher plant length values in comparison with uncoated seeds [31].

Moreover, calcium plays an important role in the synthesis of new cell walls, especially the middle lamella, which unites the cells after division, and in the cell elongation and division processes, which are closely related to growth [32].

With respect to calcium silicate, [33] also observed a positive effect of the coating of rice seeds irrigated with silicon sources on RL. The authors obtained a

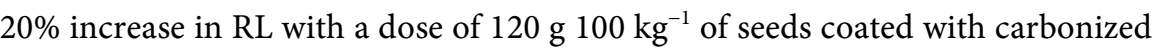
rice hulls (composed of $95 \% \mathrm{SiO}_{2}$ ). The same dose of rice hulls used by those authors promoted a $33 \%$ increase in the RL of rice cv. BRS Querência [34]. These findings corroborate ours, in which the coating with CS + PVA promoted an $18 \%$ increase in $\mathrm{RL}$, which confirms this effectiveness of calcium silicate in RL. Silicon is not classified as an essential element in plant nutrition, but its effect is analogous to that of lignin as a structural component providing resistance to the cell wall [32] [35].

None of the coating alternatives was statistically superior to control treatment for SFM, SDM, and RFM (Table 2). However, this was likely due to the high coefficients of variation $(\mathrm{CV}, \%)$ observed for these variables, which is common in results obtained from greenhouse tests, considering the high exposure to environmental variations (very high temperatures and sudden changes in humidity).

Contrastingly, the coating of barley seeds with limestone, aluminum silicate, or the combination of both provided higher plant dry matter values than those obtained with control treatment (uncoated), with increases of $79 \%$ to $146 \%$ for the limestone and limestone + aluminum silicate treatments, respectively [29]. [31] also did not observe a difference in the dry matter of soybean plants emerged from seeds coated with limestone, aluminum silicate, or the combination of both, in comparison with those from uncoated seeds. Those authors observed a $20 \%$ increase in the dry matter of soybean plants after coating the seeds with limestone and aluminum silicate.

In the present study, it should be stressed that treatments DL + S + PVA and $\mathrm{DL}+\mathrm{AC}+\mathrm{PVA}$ promoted increases of $39 \%$ and $41 \%$ for SFM, $34 \%$ and $43 \%$ for SDM, and $21 \%$ and $27 \%$ for RFM, respectively. Likewise, [11] did not find losses in SFM, SDM, and RFM for coating treatments using the same filler materials as those used here, suggesting that these are promising materials for use in seed 
coating.

By contrast, a significant difference was observed between the treatments for root dry matter (RDM) (Table 2). The DL + S + PVA coating led to the highest values for this variable, which were $74 \%$ higher than that observed in the uncoated seeds. This result also exceeded the limestone-only treatment by $115 \%$, demonstrating the improvement achieved with the presence of sand in the making of the coating.

\section{Conclusions}

Coating increases 1000-seed weight and reduces the water content of seeds. The speed and duration of germination are negatively affected by seed coating; however, this procedure does not interfere with the seed germination rate.

Plant emergence is reduced irrespective of the type of coating used. The coating treatments with limestone + activated charcoal + PVA glue or limestone + sand + PVA glue for perennial soybean cv. Comum stand out among the others in that they provide increased shoot length, dry and fresh matter of shoots, and dry and fresh matter of root.

\section{References}

[1] Costa, C., Meirellles, P.R.L., Silva, J.J. and Factori, M.A. (2008) Evolution of the Cultivated Pastures and Cattle in Brazil. Veterinária e Zootecnia, 15, 8-17.

[2] Manfredini, D. (2009) Calcium and Boron for Perennial Soybean: Anatomical and Agronomic Characteristics and Nutrient Concentrations M.sD. Dissertation São Paulo University-Superior School of Agriculture "Luiz de Queiroz", Piracicaba.

[3] Nascimento, W.M., Silva, J.B.C., Santos, P.E.C. and Carmona, R. (2009) Germination of Carrot Seed Primed and Pelleted with Several Ingredients. Horticultura Brasileira, 27, 12-16. https://doi.org/10.1590/S0102-05362009000100003

[4] Lopes, A.C.A. and Nascimento, W.M. (2012) Pelletizing in Vegetable Seeds. Embrapa Hortaliças, Brasília. 28 p. (Documentos, 137).

[5] Silva, J.B.C., Santos, E.C. and Nascimento, W.M. (2002) Performance of Pelleted Lettuce Seeds in Response to Glue Material and Temperature during the Drying of the Pellets. Horticultura Brasileira, 20, 67-70. https://doi.org/10.1590/S0102-05362002000100013

[6] Oliveira, J.A., Pereira, C.E., Guimarães, R.M., Vieira, A.R. and Silva, J.B.C. (2003) Performance of Green Pepper Seeds Covered with Different Materials. Revista Brasileira de Sementes, 25, 36-47. https://doi.org/10.1590/S0101-31222003000400006

[7] Mendonça, E.A.F., Carvalho, N.M. and Ramos, N.P. (2007) Seed Coating in Supersweet Corn $\left(\mathrm{Sh}_{2}\right)$. Revista Brasileira de Sementes, 29, 68-79.

https://doi.org/10.1590/S0101-31222007000200010

[8] Pereira, C.E., Oliveira, J.A., Guimarães, R.M., Vieira, A.R., Evangelista, J.R.E. and Oliveira, G.E. (2011) Fungicide Treatment and Film Coating of Soybean Seeds Submitted to Storage. Ciência e Agrotecnologia, 35, 158-164.

https://doi.org/10.1590/S1413-70542011000100020

[9] Baudet, L. and Peres, W. (2004) Seed Coating. Seed News, 8, 20-23.

[10] Silva, J.B.C. and Nakagawa, J. (1998a) Production and Testing of Lettuce Seed Pellets. Horticultura Brasileira, 16, 151-158. 
https://doi.org/10.1590/S0102-05361998160000200012

[11] Xavier, P.B., Vieira, H.D. and Guimarães, C.P. (2015) Physiological Potential of Stylosanthes cv. Campo Grande Seeds Coated with Different Materials. Journal of Seed Science, 37, 117-124. https://doi.org/10.1590/2317-1545v37n2145982

[12] Brasil (2009) Ministério da Agricultura Pecuária e Abastecimento. Rules for Testing Seeds. Brasília: SNDA/DNDV/CLAV, 395 p.

[13] Edmond, J.B. and Drapala, W.J. (1958) The Effects of Temperature, Sand and Soil, and Acetone on Germination of Okra Seed. Proceedings of the American Society for Horticultural Science, 71, 428-434.

[14] Maguire, J.D. (1962) Speeds of Germination-Aid Selection and Evaluation for Seedling Emergence and Vigor. Crop Science, 2, 176-177. https://doi.org/10.2135/cropsci1962.0011183X000200020033x

[15] Silva, F.A.Z. (2013) ASSISTAT-Statistical Assistance, Version 7.6. Universidade Federal de Campina Grande-PB.

[16] Magalhães, P.C., Ferreira, D.M.N., Vasconcelos, C.A., Azevedo, J.T. and Borba, C.S. (1994) Effects of Peletizing on the Germination and Development of Sorghum Cultivars. Revista Brasileira de Sementes, 16, 20-25. https://doi.org/10.17801/0101-3122/rbs.v16n1p20-25

[17] Peske, F.B. and Novembre, A.D.L.C. (2011) Pearl Millet Seed Pelleting. Revista Brasileira de Sementes, 33, 352-362. https://doi.org/10.1590/S0101-31222011000200018

[18] Acha, A.J., Vieira, H.D. and Freitas, M.S.M. (2016) Perennial Soybean Seeds Coated with High Doses of Boron and Zinc. African Journal of Biotechnology, 15, 19982005. https://doi.org/10.5897/AJB2016.15560

[19] Sousa, P.G.F. de, Vieira, H.D., Amorim, M.M. and Acha, A.J. (2016) Coating with Fungicide and Different Doses of Fertilizer in Vinhatico Seeds. African Journal of Biotechonology, 15, 2091-2097. https://doi.org/10.5897/AJB2016.15559

[20] Gadotti, C. and Puchala, B. (2010) Seed Coating. Informativo Abrates, 20, 70-71.

[21] Conceição, P.M., Vieira, H.D., Silva, R.F. and Campos, S.C. (2009) Germination and Vigor of Covered Corn Seeds and Viability of the Inoculum during Storage. Ciência e Agrotecnologia, 33, 765-772. https://doi.org/10.1590/S1413-70542009000300015

[22] Lagôa, A.O., Ferreira, A.C. and Vieira, R.D. (2012) Plantability and Moisture Content of Naked and Pelleted Seeds of Supersweet $\left(\mathrm{Sh}_{2}\right)$ Corn during Cold Storage Conditions. Revista Brasileira de Sementes, 34, 39-46. https://doi.org/10.1590/S0101-31222012000100005

[23] Medeiros, E.M., Baudet, L., Peres, W.B. and Eicholz, E.D. (2004) Modifications in Physical Condition of Carrot Seeds with Coating Equipment. Revista Brasileira de Sementes, 26, 70-75. https://doi.org/10.1590/S0101-31222004000200010

[24] Ludwig, M.P., Lucca Filho, A.O., Baudet, L., Dutra, L.M.C., Avelar, S.A.G., Crizel, R.L. and Oliveira, S. (2011) Coating Efficiency of Soybean Seeds in Equipment with Spray System. Ciência Rural, 41, 557-563. https://doi.org/10.1590/S0103-84782011005000023

[25] Franzin, S.M., Menezes, N.L., Garcia, D.C. and Roversi, T. (2004) Assessment of Vigor in Simple and Pelletizes Lettuce Seeds. Revista Brasileira de Sementes, 26, 114-118. https://doi.org/10.1590/S0101-31222004000200016

[26] Oliveira, J.A., Pereira, C.E., Guimarães, R.M., Vieira, A.R. and Silva, J.B.C. (2003) Effects of Different Pelleting Materials on the Deterioration of Tomato Seeds during Storage. Revista Brasileira de Sementes, 25, 20-27. https://doi.org/10.1590/S0101-31222003000400004 
[27] Monocha, S.M. (2003) Porous Carbon. Sadhana, 28, 335-348. https://doi.org/10.1007/BF02717142

[28] Silva, J.B.C. and Nakagawa, J. (1998b) Methods for Evaluating Cements for Seed Pelleting. Horticultura Brasileira, 16, 31-37.

[29] Corlett, F.M.F., Rufino, C.A., Vieira, J.F., Tavares, L.C., Tunes, L.V.M. and Barros, A.C.S.A. (2014) The Influence of Seed Coating on the Vigor and Early Seedling Growth of Barley. Ciencia e Investigación Agraria, 41, 129-136. https://doi.org/10.4067/S0718-16202014000100013

[30] Santos, F.C., Oliveira, J.A., Pinho, E.V.R.V., Guimarães, R.M. and Vieira, A.R. (2010) Chemical Treatment, Seed Coating and Storage of Brachiaria brizantha cv. Marandu Seeds. Revista Brasileira de Sementes, 32, 69-78. https://doi.org/10.1590/S0101-31222010000300008

[31] Rufino, C.A., Tavares, L.C., Martín-Ramos, P., Fernandes-Vieira, J., Abreu Júnior, J.S., Silva, F.J.A., Fernandes-Correa, M. and Martín-Gil, J. (2017) Performance of Soybean Seedlings upon Nutrient Application by Seed Coating. Brazilian Archives of Biology and Techonology, 60, 1-11. https://doi.org/10.1590/1678-4324-2017160128

[32] Taiz, L. and Zeiger, E. (2006) Plant Physiology. 4th Edition, Sinauer Associates, Inc.

[33] Tunes, L.V.M., Fonseca, D.A.R., Meneghello, G.E., Reis, B.B., Brasil, V.D., Rufino, C.A. and Vilella, F.A. (2014) Physiological, Health and Enzymatic Quality of Irrigated Rice Seeds Coated with Silicon. Revista Ceres, 61, 675-685. https://doi.org/10.1590/0034-737X201461050011

[34] Oliveira, S., Brunes, A.P., Lemes, E.S., Tavares, L.C., Meneghello, G.E., Leitzke, I.D. and Mendonça, A.O. (2016) Rice Seed Treatment with Silicon and Seed Quality. Revista de Ciências Agrárias, 39, 202-209. https://doi.org/10.19084/RCA15083

[35] Epstein, E. (1994) The Anomaly of Silicon in Plant Biology. Proceedings of the National Academy of Sciences, 91, 11-17. https://doi.org/10.1073/pnas.91.1.11 